Catherine Baker

Department of Modern Languages, School of Humanities, University of

Southampton, Highfield Road, Southampton, SO17 1BJ, United Kingdom.

\begin{abstract}
From the outbreak of the Homeland War (1991-95) in Croatia to the present day, popular music has been used as a means to commemorate the upheaval and sacrifice of Croatia's war against the Yugoslav National Army and the Serb militia. This paper focuses on the musical commemoration of a particular region, eastern Slavonia, which was not fully integrated into the Croatian state until three years after the official end of the war. The narrative, vocabulary and symbols established during the immediate wartime phase have persisted into the present day when war memory has become inflected by post-war developments such as the indictment of Croatian Army officers for war crimes.

Biography

Catherine Baker is a post-doctoral research assistant at the University of Southampton. She received her PhD in 2008 from the School of Slavonic and East European Studies, UCL, for her thesis titled "Popular music and narratives of identity in Croatia since 1991". Her articles have appeared in Ethnopolitics, Popular Communication and Nationalities Papers.
\end{abstract}

Contact

cbakertw1@googlemail.com 


\section{War Memory and Musical Tradition: Commemorating Croatia's Homeland War through Popular Music and Rap in eastern Slavonia ${ }^{1}$}

The conflict known in Croatia as the Homeland War, part of the wider conflict surrounding the disintegration of Yugoslavia, lasted from July 1991 to August 1995 after Croatia declared independence from Yugoslavia at the end of June 1991. The advance of the Yugoslav National Army (Jugoslavenska narodna armija, JNA) into territory claimed by Croatia in the regions of Slavonia and Krajina aimed to prevent Croatia seceding and support Croatian Serb rebels whose increasingly violent confrontations with the Croatian police had begun in August 1990. By the time the front(s) had stabilised in early 1992, approximately a third of Croatian territory was under occupation, and the easternmost parts of Slavonia did not even come under full Croatian control until January 1998 when a United Nations Transitional Administration (UNTAES) expired. In Croatia the Homeland War was memorialised by state and non-state actors as soon as it had begun, in order to mobilise support for the war effort and government, to homogenise the majority ethnic community around a desired narrative of the war and to attract international stakeholders to the Croatian interpretation of the conflict. The Homeland War and its victorious outcome are still officially commemorated today as the founding narrative of the Croatian state, and representations of the conflict remain a common theme in popular culture and entertainment.

This article explores how the memory of the war in a particular region (eastern Slavonia) has been represented in popular music between 1991 and the present day. Representations of the conflict fall into three phases: the immediate wartime period, which established the narrative, vocabulary and symbols for future commemorations 
of the war; the ambiguous post-conflict period when eastern Slavonia had still not been fully reintegrated into the Croatian state; the present day when war memory has been inflected by post-war developments such as the indictment of Croatian Army officers for war crimes and when the generation who were children during the Homeland War are now adults (some of them active musicians). The key themes in wartime representations of Slavonia have still been maintained into the present day.

\section{Popular Music during the Homeland War}

Between August 1991 and spring 1992, the months of fiercest fighting in the Homeland War, almost every active professional musician in Croatia joined in a wave of patriotic popular music production. New patriotic songs provided the material for fundraising cassettes and concerts (in Croatia and among the Croatian diaspora) and filled gaps between rolling news items on Croatian state television (Hrvatska televizija, HTV), which had itself tendered for patriotic music in late August 1991 and sponsored many audio and video recordings. HTV's representation of the war harmonised with the dominant narrative of the Croatian side of the war put forward by the president, Franjo Tuđman: Croatia was thus presented as an innocent, nonaggressive party reluctantly but steadfastly defending itself against the Serbian 'aggressor' (a combination of the JNA, Slobodan Milošević and Croatian Serb rebels). The HTV/presidential narrative extended beyond news to music: HTV did not support songs which contravened its wider aims (if for instance they implied that Croatian soldiers were themselves aggressive), could ask for images in lyrics or videos to be changed, and on several occasions removed songs from playlists because editors had apparently had second thoughts about their connotations. 
Wartime popular music referred to history, religion, gender, present-day narratives about the nation and its enemies, current politics and - in a conflict characterised by pictures of fleeing refugees and occupied villages - territory. Before the war, Croatian popular music (and ex-Yugoslav pop in general) had developed a strong tradition of songs about hometowns/home regions which used local lexis and instrumentation to reinforce their association with a particular place: thus songs about the coastal region of Dalmatia would use mandolins, the region's Italian-influenced dialect and images of coastal activities, while songs about Slavonia would use a tamburica (a stringed instrument resembling a bouzouki or balalaika) and include words and images from everyday life in the farming villages of the Slavonian plain. Performers, who tended to be male, would sing about a place they were connected to themselves (one of the Croatian diaspora's favourite singers, Tomislav Ivčić, came from Zadar and would therefore sing about that city rather than Split or Dubrovnik) and usually expressed longing for their town/region. This style of music-making continued during the war but added contemporary wartime experiences to its depictions of place. Since many Croats experienced the war primarily through displacement (as refugees themselves; as friends or relatives of refugees; as hosts to refugees displaced from their own homes), the lexis of 'hometown' songs arguably served as a way to communicate a narrative of the war in language made familiar through pre-war showbusiness. The central theme of longing for home persisted, but was construed as the aftermath of aggression against the nation rather than the result of economic migration.

While almost every besieged or occupied town was commemorated in wartime popular music at some point, Slavonia probably inspired the largest body of regionally-themed wartime music. The region was one of the two key battlefronts in 
the Homeland War and contained the famous town of Vukovar, where - according to a quickly-established myth - Croatian 'defenders' ('branitelji') had held out against much greater JNA forces until the JNA and Serb paramilitaries brutally captured the town in November 1991. The state media quickly established Vukovar alongside Dubrovnik as a key site of national resistance and victimhood (Senjković, 2002), even though rumours continued to circulate that Vukovar might not have fallen if the Croatian state had allocated more resources to its defence (Kardov, 2007: 64). However, the amount of wartime music dedicated to Slavonia was not simply a product of political expedience. Slavonian tamburica music had become commercially successful in the 1980s thanks to the group Zlatni dukati, whose move towards patriotic Croatian songs in 1989 placed them among the first Croatian musicians to sing about the nation (Bonifačić, 1998: 139-47). While continuing to revive 19th- and 20th-century songs, Dukati also composed new material and in particular dedicated themselves to memorialising Vukovar (their first Vukovar song, Vukovar, Vukovar, appeared during the siege). In press appearances the bandleader Josip Ivanković reinforced their claim to speak for Vukovar by mentioning that several band members came from nearby towns and that their last Vukovar concert had occurred shortly before the May 1991 massacre of Croatian policemen in a local suburb, Borovo Selo. He pledged to dedicate a song to Vukovar on every album '[u]ntil it's free' (Brkan, 1993) and that Dukati, as the last tamburica band to perform in Vukovar before the war, would also be the first afterwards (Stažić, 1995). ${ }^{2}$

Dukati also helped popularise the most famous Slavonian song from the Homeland War, Miroslav Škoro's Ne dirajte mi ravnicu (Don't Touch my Plains). Škoro had actually written it as a song about economic emigration while living in the USA and sent a demo to the main Croatian record label (then Jugoton; Croatia 
Records from August 1991). A Croatia Records executive found it in the archives while assembling a compilation of patriotic tamburica songs in autumn 1991 and gave it its title: it had originally been called Ja ću se vratiti (I'll Return) and related to economic migrants rather than refugees (Pukanić, 1993), further indicating the convergence between pre-war hometown songs and wartime patriotic ones. By the time versions of Ravnica by Dukati and Škoro both became hits in early 1992, the battlefront had stabilised with a third of Croatian territory under Serb occupation and displacement was therefore an ongoing social reality. To many refugees, Škoro’s nostalgia for his plains, tamburica and mother summed up their own longing to go back home (March, 2003: 175). It was little wonder émigrés and refugees saw it as 'a symbol of protest and resistance' (Bonifačić, 1998: 146), nor that journalists used its title as a figure of speech when looking forward to Croatia resuming sovereignty over the occupied territory. Ravnica contained no place-names or ethnic identifiers, but was coded as Slavonian through its tamburica arrangement and its references to plains. Editors and event organisers could easily assimilate it into a collective narrative of displacement which would be overcome.

\section{Commemorating eastern Slavonia and Vukovar, 1995-98}

Displacement from eastern Slavonia was not overcome as quickly as the Croatian state, media or Croat refugees had hoped. The Homeland War officially came to an end in August 1995 when the Croatian Army recaptured the breakaway Serbs' 'capital' of Knin and advanced into Slavonia, but the peace agreement provided that eastern Slavonia should be placed under UN administration rather than passing under Croatian sovereignty immediately. The ambiguity over eastern Slavonia disrupted the teleological narrative of Tuđman, who had presented himself as the individual who 
would fulfil the Croatian people's 'thousand-year dream' of sovereignty over their own territory (Bellamy, 2000; Žanić, 1995). Sovereignty would not be complete until eastern Slavonia (and especially the enduring symbolic site of Vukovar) was reintegrated into the Croatian state. Indeed, the extension of UNTAES's mandate into January 1998 somewhat overshadowed Tuđman's presidential election campaign in 1997 under the slogan 'All the Croatian victories for Vukovar'. ${ }^{3}$ Tuđman was able to visit Vukovar by train along the rebuilt railway line, maintaining the symbolism of his celebratory train ride to Knin in 1995, but his reception in Vukovar was scrutinised by UNTAES, partially restricting Tuđman's powerful publicity office. The state tabloid Večernji list claimed that UNTAES had vetted the reception programme so as not to offend local Serbs and had even banned Ravnica being performed at the ceremony although the crowd apparently sang it anyway (Glavina et al., 1997). Vukovar was fundamentally integrated into the 'banal nationalism' (Billig, 1995) of 1990s Croatia, which injected routinised commemorations into everyday life. The state took the lead by placing Vukovar onto banknotes and medals as well as by organising commemorative events, but many non-state actors - from writers and musicians to café owners - took up the narrative by commemorating Vukovar themselves (Kardov, 2007: 65-6). Although the impetus to produce patriotic music died down after the war, music about eastern Slavonia was an exception. During the war there had already been songs looking forward to the region's reintegration: for instance, one 1993 song by Zlatko Pejaković described Dalmatia’s separation from Slavonia by accompanying references to each region with a corresponding phrase on the mandolin or tamburica (after the key change they joyfully played together to symbolise reintegration). Gazde, the foremost band in the music industry's mid-1990s push to develop a national popular music based on tamburica, also dealt with the 
theme of displacement on their 1995 song Još i danas zamiriše trešnja (The Cherrytree's Scent still Remains Today). ${ }^{4}$ Its composer Miroslav Rus once said it had been inspired when his friend Tomislav Marčinko (HTV's deputy news editor during the war) remembered leaving Vojvodina (in northern Serbia) for Croatia in 1990 (Maksimović, 1996). Images of co-existence shattered by so-called 'former neighbours' were a frequent element of displacement discourse, as was sadness at the loss of family memories and social status embodied in lost homes and farms (see Čapo Žmegač, 2007: 51-2) - although the story does also hint at certain musicians’ closeness to power.

Although some songs which alluded to eastern Slavonia were part of everyday showbusiness promotion, a key site for memorialising the region's war experience was the Review of Patriotic Songs (Brodfest) in the Slavonian town of Slavonski Brod, which launched in 1992. Between 1992 and 1998, every Brodfest contained several songs which responded to the new conditions of everyday life in (or often away from) Slavonia, again expressing wartime displacement through the existing devices of Slavonian 'hometown' songs (e.g. asking a river or bird to take a message to/from the home region) and narrating the effects of the war in familiar terms. Brodfest songs emphasised the nation's connection to the land through representations of everyday life and the idea of home, while history was a matter of timeless local tradition rather than great leaders or events. The liberation of Knin in August 1995, which was immediately celebrated nationally as the end of the war, actually had little effect on the Brodfest representations of Slavonia: indeed, Vukovar was now the last unresolved issue of the war and thus all the more important after 1995.

Brodfest songs which narrated the conflict involved consistent themes of territory and custom. Two songs by the tamburica band Slavonski bećari in 1994 and 1997 
epitomised the festival's discourse of war memory about Slavonia. The first, Istinu svijetu o Baranji reci (Tell the World the Truth about Baranja ${ }^{5}$ ), asked the neighbouring Danube and Drava rivers to 'tell the world the truth about' where they lived. 'We' were a peaceful people who liked making ham, salami and wine (traditional Slavonian fare), but now the narrator had been separated from his son, cold steel was falling from the sky, the sound of the tamburica had been replaced by that of a rifle, yet the ancestors of the 'Šokci' (Baranja peasants) were crying out to them not to give up. The second, Hrvati će Baranju imati (The Croats will have Baranja) looked forward to the region's eventual reintegration. This time the narrator asked a falcon (a typical folkloric bird) to greet his fields, meadows, vineyards and wine-cellars in Baranja, check whether Baranja was whole or the villages had been destroyed and tell everyone that the narrator too would be coming home, with which 'the Croats will have Baranja'.

Religion in this repertoire was ostensibly an aspect of customary life and another bond to the territory; its function as an ethnic marker (of Catholic Croats and Orthodox Serbs) was never mentioned. Many songs looked forward to everyday life and customs returning, which might include the ringing of church bells or a future marriage (once separated male soldiers and female needleworkers had been reunited). The corollary of a future where everyday customs would return was a present where they were absent: some songs even suggested there was no life at all in occupied Slavonia. One song by Đurđica Pleše in 1994 (Vratit će se život u našu ravnicu - Life will come back to our Plains) listed all the everyday occurrences which were not happening on the plains: no quinces in the gardens, no grandfathers brewing brandy, no horses going down the street, no sound in the fields and no youths kissing girls, but the people and old customs would return and Slavonia would flower again. The 
imagery of emptiness had problematic implications for the memory of Croat-Serb coexistence, since a (disrupted) everyday life was still going on for Serbs who had remained or been relocated to occupied Slavonia. The discursive emptiness of the occupied territory, however, excised them from memory. This supports Kruno Kardov's observation that '[f]or Croats, Krajina was not just an ethnically cleansed area but an utterly empty region - a region where it is therefore impossible to dwell' (2007: 66). The option of heterogeneity had had to be eradicated in the media war (which extended to music) as much as in the physical conflict itself, which required every individual to be primarily defined along monoethnic lines (Žarkov, 2007: 5). The patriotic adaptation of the hometown-song model conveyed sentiments about place by mediating the lived experience of home with the abstraction of the homeland and the nation. The manner of mediation is reminiscent of Heimat poetry and visual imagery in Imperial Germany: whether in official propaganda, tourism material or consumer goods, the Heimat mediations placed 'the impersonal nation [...] within the familiar local world' so that the concept of belonging to a nation could be communicated effectively (Confino, 1997: 9). However, the content of the idealised landscape differed to reflect Croatia's geographic situation. The gentle hills of German Heimat imagery were universal, but Croatian (and Yugoslav) national thought played on the complementary nature of the plains and the coast, reflecting a classic paradigm in Croatian ethnology of the 'Pannonian' and 'Adriatic' cultural areas. ${ }^{6}$ The plains/coastal duality recurred throughout the 1990s in images of post-war reintegration, from Zlatko Pejaković's song about the tamburica and the mandolin to the joint memorialisation of inland Vukovar and coastal Dubrovnik as the twin sites of national victimhood. However, the delay in reintegrating Vukovar made it the focus of ongoing symbolic work after the end of the war. A linear process of 
suffering, displacement, nostalgia/sadness and return was enshrined in political discourse, the mass media, school textbooks and Brodfest songs about Vukovar. However, once Vukovar was reintegrated after the UNTAES mandate ended in January 1998, its devastation became the state's problem. Brodfest began to concern itself with a more abstract narrative of nationhood composed of different regions, perhaps reflecting the narrative that after Vukovar's reintegration 'the stabilization of Croatian identity' could now take place (Kardov, 2007: 67). The challenges of rebuilding everyday life were not material for the idealised representations of patriotic music. ${ }^{7}$

\section{Vinkovci Rap: Commemorating the War in Slavonian Hip-Hop}

The third phase of patriotic music, which emerged in the late 1990s and gathered pace after Croatia's change of government in 2000 , dealt with disappointment at the postwar settlement as well as love of the homeland. The upsurge of oppositional patriotic music in the early 2000s (particularly associated with Marko Perković Thompson and Miroslav Škoro) coincided with a protest movement against the trials and extraditions of Croatian Army officers indicted for war crimes during the Homeland War (see Fisher, 2003; Schäuble, forthcoming). According to Tuđmanist logic in the 1990s, it was impossible to commit war crimes in a defensive action like the Homeland War because any act carried out in a just cause was itself justified. This discourse was challenged by Tuđman’s successor as president, Stjepan Mesić (who freely cooperated with the international war crimes tribunal in The Hague), but was maintained by the politicians, activists, veterans and demonstrators who supported the cause of two indicted Croatian generals (Mirko Norac and Ante Gotovina). 
Thompson's music expressed disappointment with the treatment of the indicted officers, with the perceived lack of respect accorded to veterans in general in post-war Croatian society and with the failure of the Croatian state to incorporate Herzegovina (the area of Bosnia-Herzegovina where most Bosnian Croats lived) (See Senjković and Dukić, 2005: 51-2). His own background as a veteran - in 1992, while serving as an army volunteer in a unit raised to defend his home village, he had become a showbusiness star with a song written at the front - supported his claim to speak on behalf of other veterans after the war. However, he became an increasingly divisive figure in 2002-05 as he spoke out against the centre-left government of 2000-03 (which included a socialist party of reformed Communists) and journalists built up arguments that during concerts Thompson celebrated the memory of the Independent State of Croatia (Nezavisna država Hrvatska, NDH), the puppet Croatian state within the Axis. Miroslav Škoro's songs about betrayed heroes covered similar ground (such as frequent references to national history and a mythic medieval period) but avoided political allusions or any suspicion of extremism (Jergović, 2005).

The music of Dalibor Bartulović-Shorty, a rapper from Vinkovci near the Serbian border in eastern Slavonia, emerged within this context. Shorty crossed over from the Croatian hip-hop scene to mainstream showbusiness in 2004 when he released a song about Vinkovci, Slavonia and the war which sampled the chorus of a tamburica song called Dođi u Vinkovce (Come to Vinkovci) from the mid-1990s which had been performed at Brodfest. He performed the new song, with the same title, at Brodfest in 2005 and it was taken up by the powerful radio station Narodni radio. $^{8}$ Dođi $u$ Vinkovce crossed over so successfully because, despite its rap vocal, it was consistent with existing conventions of home/homeland imagery, retained the tamburica (looped throughout the song) and supported the dominant narrative of the 
war in eastern Slavonia. Its three verses dedicated a verse each to the narrator's pleasure in his immediate home, the beauty of his region (Slavonia) and its sacrifice and defiance during the Homeland War, all connected by the chorus of the 1995 song which called on the listener to go back to Vinkovci if s/he was longing for the plains. The song claimed continuity with the rich tradition of Slavonian tamburica music by drawing on the same regional lexis for the local landscape and customs and by alluding to a tamburica standard, Gori lampa nasrid Vinkovaca (A Lamp Burns in the Middle of Vinkovci), in a line locating the narrator's home. Such a technique resolved the potential generational conflicts of the hip-hop form by situating the narrator (and thus the performer) as a young man who was aware and respectful of his ancestors' traditions. Indeed, his connection with his ancestors extended to his awareness that the sleeping bones of his ancestors tied him to his home - repeating an often-nationalised discourse of grave sites where territory is marked as "ours" through the conjunction of 'our' sons and 'our' soil (Verdery, 1999). The central chorus about emigrants' nostalgia was bracketed by a linear flow of time from an imagined rural idyll to the effects of Homeland War devastation on Slavonia. These latter sections continued the narrative of Slavonia as Croatia's beleaguered but heroically resistant front line. The conflict itself was represented as a stark aggressor/defender opposition where an impersonalised enemy, 'they', had burned down 'our' forests and houses and killed 'our' people, but 'we' had stayed on 'our' own land and rebuilt our property, thus confirming 'our' rightful possession of the land. The gains won by the sacrifice of Slavonian sons - freedom and mastery of one's own land - were identical to the official war aims of the Croatian state. ${ }^{9}$ Meanwhile, another intertextual reference to the title of Škoro's Ne dirajte mi ravnicu further wove the song into tamburica tradition. $^{10}$ 
Dođi $u$ Vinkovce provided Shorty with a major hit but was not universally welcomed within Croatian hip-hop, especially not by those who considered hip-hop part of the 'alternative' and valued resistance towards dominant discourses and nationalism. The song's uptake by Narodni radio gave reason to accuse Shorty of hiphop's ultimate sin, 'selling out'; by contrast, another hip-hop song about Vukovar by General Woo (one of Zagreb's top MCs, who had arrived in the capital in 1991 as a teenage refugee from Vukovar) never achieved the mainstream success of Dođi $u$ Vinkovce. General Woo's song, Vrati se na Dunav (Come back to the Danube), mentioned the fall of Vukovar, missing persons and Vesna Bosanac (a Croatian doctor captured when Vukovar fell) but laid its emphasis on improving life for young people in conditions of economic uncertainty (eastern Slavonia is still one of the most economically depressed parts of Croatia), something which had not even been mentioned in the idyll of Dođi $u$ Vinkovce. The song showed that convergence with established politicised representations of Slavonia was not the only available representational strategy for conveying Homeland War memory through popular music. However, Shorty articulated a coherent narrative of identity which unproblematically connected the individual to the perceivable region and the abstract nation through established textual conventions and was therefore better suited to a mainstream which did not challenge widespread political assumptions.

Shorty's second album, released in 2007, built on the success of Dođi $u$ Vinkovce and responded to its reception. In this regard the most important track was the single Heroji danas (Heroes Today), where Shorty contrasted his own respect for war memory with the disrespect shown by Croatians who pandered to Europe (including the European Union's demands to extradite war crimes indictees) and failed to grasp the authentic values he himself cherished. ${ }^{11}$ Shorty framed Heroji 
danas as a song for Blago Zadro (the popular commander of the defence of Vukovar, who had died during the siege) and the Graveyard of Tanks (a place outside Vukovar where lightly-armed Croatian soldiers had destroyed JNA tanks), then attacked the longing for Europe on the part of Croatians who had handed over 'heroes' to The Hague. He also discussed his own persona, situated himself as a patriot not a nationalist, and invited critics who thought of him as a peasant to go and see where the crosses were (i.e. to consider Slavonia's sacrifices for freedom) before reminding them that at least he knew who he was and they apparently did not - and that many people had liked Dođi u Vinkovce.

By rejecting the 'peasant' label and mocking his critics' fear of the Balkans, Shorty directly confronted 'anti-nationalist' discursive practices which associated nationalism with a village mentality (see Jansen, 2005). For Shorty, what certain others considered 'nationalism' was his legitimate respect for the war's memory, and he not they could claim fully realised selfhood. Like the veteran Thompson, Shorty could derive moral authority from his war experience: he once said his opponents 'have no idea, because they weren't here', while 'I was in Vinkovci in 1991 and I know what I'm talking about' (Mila, 2007). The dominant narrative of the Homeland War could accommodate Thompson as a member of one identifiable group (veterans); Shorty, a child in 1991, belonged to another social group which had been equally as important in wartime ideology.

Instead of reconciling Shorty with his critics, Heroji danas seemed to confirm their perceptions of each other. Whereas in 2005 the magazine Globus had included Shorty among the 'new new wave' of alternative musicians in Croatia (Jindra, 2005), ${ }^{12}$ his membership of the alternative was seriously called into question after Heroji danas - most of all by the rock critic Ilko Čulić, whose scathing review called 
Shorty 'the Škoro of rap' and concluded that he was 'closer to HIP than hip-hop' (Čulić, 2007). ${ }^{13}$ The video for Heroji danas, made a few months later, directly hit back at Čulić as well as reinforcing the messages of the song itself. The video combined scenes of Shorty behind bars being classified as 'arrogant' and 'aggressive' by an EU observer, archive footage of soldiers and refugees from the Homeland War, pictures of Shorty walking around Vukovar in the present day (often in the same locations or at local monuments) and mocked-up newspaper headlines - including one which ridiculed Čulić by name. The video ended with an excerpted report by Siniša Glavašević, the young journalist from Croatian Radio Vukovar who had famously sent dispatches from cellars in the besieged town and been treated as a hero after disappearing during the siege. ${ }^{14}$ As distasteful as Čulić himself might have found Heroji danas, it nonetheless indicated how so-called nationalists were increasingly using music to respond to their constant othering by liberal-leaning writers and artists.

\section{Conclusion}

Hip-hop, a product of Black Atlantic musical culture (Gilroy, 1993: 95), has provided musicians in many other places with a means to comment on social and political affairs in their own environment and to quite literally represent (to depict and to stand up for) their locality (Solomon, 2005: 16). The 'hip hop cartography' of the USA is organised around particular city districts and rappers narrate the personal meanings of these places to them through their lyrics (Forman, 2000: 67). The European appropriation of hip-hop can be seen as 'a creative integration of rap into the host culture', whereby local concerns, national or regional language and the sampling of local audio material produce an 'indigenized' version of the US hip-hop model (Androutsopoulos and Scholz, 2003: 468). This is certainly the case in Croatia, where 
hip-hop scenes are associated with particular cities and use the corresponding regional dialects as well as other indigenizing practices: thus the Tuzla-born MC Edo Maajka, based in Zagreb, uses samples of Bosnian sevdah music to narrate his own origin growing up in Bosnia (Bosanac, 2004: 119).

Dalibor Bartulović's memorialisation of the Homeland War through hip-hop is therefore very much in keeping with the European transformation of the form, even though gatekeepers of the 'alternative' in Croatia have considered that his acceptance of a politically conformist narrative about the war transgresses their norms of cultural engagement - and even though tamburica purists might have been horrified during the 1990s popularisation of the instrument to think that tamburica pop would eventually spawn tamburica rap. Shorty's integration into the mainstream of Croatian showbusiness with Dođi $u$ Vinkovce, owed largely to the promotional power of Narodni radio, supported the music industry's belief (derived from the high sales of Marko Perković Thompson) that commemorative pop was profitable. The use of hiphop to support the prevailing representation of the Homeland War might undermine the common belief in ex-Yugoslav urban culture that localised folk-based music is inherently right-wing and cosmopolitan musical forms (such as rock and rap) are inherently progressive. ${ }^{15}$ In practice, the nature of Shorty's politics has instead led to him being classified through the same discursive apparatus which is applied (fairly or unfairly) to folk.

The Shorty phenomenon is simply the latest phase of a longer-term memorialisation process in Croatia, based on practices established during and even before the war itself. Political circumstances have varied during the phases of occupation, reintegration and post-conflict reflection. The imagery used to represent the war has still remained remarkably consistent and conveys interpretations and 
sentiments about the conflict by mediating the concepts of home and homeland through conventions already laid down in pre-war Croatian/ex-Yugoslav showbusiness. Contemporary music does also offer ways to argue that war memory is not the most important issue in contemporary Slavonia. The opportunities for media and commercial success are nonetheless still greatest for texts which unproblematically employ the representation of the war established by the 1990s state.

\section{References}

Androutsopoulos, Jannis, and Arno Scholz (2003) 'Spaghetti Funk: Appropriations of Hip-Hop Culture and Rap Music in Europe', Popular Music and Society 26:4, 46379.

Bellamy, Alex J (2000) 'Breaking the Curse of King Zvonimir: the Nationalist Narrative of Franjo Tudjman', Slovo 12, 1-17.

Billig, Michael (1995) Banal Nationalism, London: Sage.

Bonifačić, Ruža (1998) 'Regional and National Aspects of Tamburica Tradition: the Case of the Zlatni dukati Neotraditional Ensemble', in Svanibor Pettan (ed.), Music, Politics and War: Views from Croatia, Zagreb: Institute of Ethnology and Folklore Research, pp. 131-49.

Bosanac, Jana (2004) 'Transkulturacija u glazbi: primjer hrvatskog hip hopa', Narodna umjetnost 41:2, 105-22.

Brkan, Božica (1993, 13 June) 'Pjesmom u Vukovar', Večernji list. Čapo Žmegač, Jasna (2007) Strangers Either Way: the Lives of Croatian Refugees in their New Home, Oxford: Berghahn. 
Confino, Alon (1997) The Nation as a Local Metaphor: Württemberg, Imperial Germany, and National Memory, 1871-1918, Chapel Hill, NC: University of North Carolina Press.

Čulić, Ilko (2007, 6 April) 'Glasnogovornik hip-hop desnice', Jutarnji list.

Fisher, Sharon (2003) 'Contentious Politics in Croatia: the War Veterans'

Movement', Petr Kopecký and Cas Mudde (ed.), Uncivil Society?: Contentious

Politics in Post-Communist Europe, London and New York: Routledge, pp. 74-92.

Forman, Murray (2000) “"Represent”: Race, Space and Place in Rap Music', Popular Music 19:1, 65-90.

Gilroy, Paul (1993) The Black Atlantic: Modernity and Double Consciousness, Cambridge, MA: Harvard University Press.

Glavina, Diana, et al. (1997, 9 June) 'Vlak za koji je Hrvatska živjela', Večernji list. Jansen, Stef (2005) Antinacionalizam: etnografija otpora u Beogradu i Zagrebu, Belgrade: Biblioteka XX vek.

Jergović, Miljenko (2005, 28 October) 'Thompson nove vlasti', Globus.

Jović, Dejan (2006) 'Croatia and the European Union: a Long Delayed Journey’, Journal of Southern Europe and the Balkans 8:1, 85-103.

Kardov, Kruno (2007) 'Remember Vukovar: Memory, Sense of Place, and the National Tradition in Croatia', in Sabrina P Ramet and Davorka Matić (ed.), Democratic Transition in Croatia: Value Transformation, Education and Media, College Station, TX: Texas A\&M University Press, pp. 63-88.

Maksimović, Andrej (1996, 11 October) “"Croatija Records” zabranila je "Barune”, Nacional.

March, Richard (2003) 'Globalno “selo moje malo”: suvremeno tamburaško glazbovanje u Sjedinjenim Američkim Državama', Narodna umjetnost 40:2, 169-79. 
Mila, Samir (2007, 1 June) 'Slavonac sam i ponosim se time', Novi tjednik.

Pettan, Svanibor (1996) 'The Croats and the Question of their Mediterranean Musical Identity', Ethnomusicology OnLine 3, http://research.umbc.edu/eol/3/pettan/ [accessed 6 November 2006].

Pukanić, Ivo (1993, 17 December) 'Kad se američka doktorica prava udala za mene, njen otac je poludio', Globus.

Schäuble, Michaela (forthcoming) 'Contested Masculinities: Discourses on the Role of Croatian Combatants during the "Homeland War" (1991-1995)', Christine Eifler and Ruth Seifert (ed.), Gender in Armed Conflicts and in Post-War Reconstruction. Senjković, Reana (2002) Lica društva, likovi države, Zagreb: Biblioteka Nova etnografija.

Senjković, Reana, and Davor Dukić (2005) 'Virtual Homeland?: Reading the Music on Offer on a Particular Web Page', International Journal of Cultural Studies 8:1, $44-62$.

Solomon, Thomas (2005) “"Living Underground is Tough": Authenticity and Locality in the Hip-Hop Community in Istanbul, Turkey', Popular Music 24:1, 1-20.

Stažić, Igor (1995, 8 June) 'Prvi smo s tamburicama ušli u Okučane a sada se spremamo ući u u Vukovar', Arena.

Verdery, Katherine (1999) The Political Lives of Dead Bodies: Reburial and Postsocialist Change, New York: Columbia University Press.

Vučetić, Ana (2005, 10 December) 'Đaci zapalili zastavu EU-a', Slobodna Dalmacija.

Žanić, Ivo (1995) 'The Curse of King Zvonimir and Political Discourse in Embattled Croatia', East European Politics and Societies 9:1, 90-122. 
${ }^{1}$ This research was supported by the Arts and Humanities Research Council. I would like to thank Wendy Bracewell, Eric Gordy, Jelena Obradović and Téa Sindbaek for comments on earlier versions of this paper.

${ }^{2}$ All translations are the author's own.

${ }^{3}$ During the campaign, Croatia Records released a compilation of patriotic songs with the same title, suggesting that the firm (at least under its then management)

participated in the ostensibly apolitical political project.

${ }^{4}$ It has since been covered by the Montenegrin singer Bojan Bajramović and the late Macedonian singer Toše Proeski (who had a posthumous hit with it in Croatia); both removed the tamburica.

${ }^{5}$ North-eastern Slavonia.

${ }^{6}$ The paradigm also included a third, 'Dinaric' area, the highlands of the Dalmatian hinterland and Herzegovina. This cultural area tended to be pejoratively associated with 'the Balkans' and was systematically marginalised during the 1990s (Pettan, 1996). One of the many interlocking reasons Croatians might express dislike of Marko Perković Thompson, a well-known patriotic singer, was that his music incorporated Dinaric vocal/musical practices.

${ }^{7}$ This itself different from socialist Yugoslavia, where the cult of industry ensured the large body of pro-regime pop-songs included some about construction/renovation.

${ }^{8}$ The only national station with an entirely Croatian playlist. It regularly plays 'hometown'/patriotic songs, and rarely plays hip-hop.

${ }^{9}$ Significant, too, that they were 'sons': the song's gender portrayals were consistent with wartime and pre-war imagery of male friends or soldiers as the sons of a maternal landscape which can reappear as a fairy (the 'Slavonian fairy' was mentioned at one point) and of male comradeship (cemented by drinking and righteous combat) being more important than female company. The song's only nonmythical woman was the narrator's mother, praised for raising him as a good Slavonian male.

${ }^{10}$ Likewise a 2007 song (Nije na prodaju - Not for sale) by the tamburica ensemble Mladi šest, attacking the selling-off of islands/waterways by politicians who used to be atheist Communists, alluded to Ravnica and wartime sacrifice while warning them to leave the plains alone because people had died for them.

${ }^{11}$ Dejan Jović (2006: 90) argues 'Europe' replaced Yugoslavia as a fundamental Other in Croatia during late Tuđmanism when the EU began to demand co-operation with The Hague; thereafter the EU delayed Croatia's accession talks at British-Dutch request because of the Croatian government's alleged failure to share intelligence on Gotovina's whereabouts. Euroscepticism and support for Gotovina were often mutually reinforcing, as when Zadar teenagers burned an EU flag after Gotovina's arrest (Vučetić, 2005). 
12 The original 1980s "new wave" denoted an explosion of creativity among Croatian and other Yugoslav rock bands.

${ }^{13}$ HIP (Hrvatski identitet i prosperitet, Croatian Identity and Prosperity): the fringe right-wing party led by Tuđman's son Miroslav.

${ }^{14}$ Glavašević was twice commemorated at Brodfest: once in a 1993 song where Šima Jovanovac (the festival director) promised him a familiar male friendship experience

- sitting down with "us" while tamburica music soothed his pain - if he returned, and again in 1999 by Viktorija Kulišić-Đenka after he was confirmed dead.

${ }^{15}$ Thanks to Eric Gordy for this point. 